\title{
Exposure to elevated temperatures and hydrogen peroxide elicits oxidative stress and antioxidant response in the Antarctic intertidal limpet Nacella concinna
}

\author{
Doris Abele $^{\mathrm{a}, *}$, Bruno Burlando ${ }^{\mathrm{b}}$, Aldo Viarengo ${ }^{\mathrm{b}}$, Hans-Otto Pörtner ${ }^{\mathrm{a}}$ \\ a Alfred Wegener Institute for Polar-and Marine Research, Bio 1, Box 120161 Columbusstr., \\ D-27568 Bremerhaven and University of Bremen FB 2, Marine Zoology, 28359 Bremen, Germany

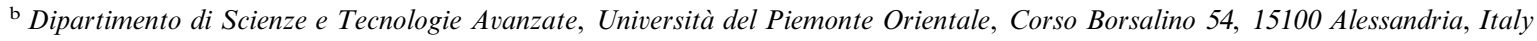

Received 21 November 1997; received in revised form 1 April 1998; accepted 7 April 1998

\begin{abstract}
This study deals with the occurrence of oxidative stress and antioxidant response in the Antarctic intertidal limpet Nacella concinna, as an effect of temperature increments and $\mathrm{H}_{2} \mathrm{O}_{2}$ exposure under controlled laboratory conditions. Experiments were designed to simulate transient conditions of increased $\mathrm{T}$ and $/$ or $\mathrm{H}_{2} \mathrm{O}_{2}$ accumulation met by the limpets in intertidal rockpool habitats [5]. Specimens were collected at Jubany Station, South Shetland Islands, transferred to the Alfred-Wegener Institute, Bremerhaven and maintained in seawater aquaria at $0^{\circ} \mathrm{C}$. Different groups of animals were acclimated at 4 and $9^{\circ} \mathrm{C}$ for $24-48$ $\mathrm{h}\left(\right.$ controls at $0^{\circ} \mathrm{C}$ ). The effect of starvation was studied at $0^{\circ} \mathrm{C}$ and of $\mathrm{H}_{2} \mathrm{O}_{2}$ exposure at $4^{\circ} \mathrm{C}$. Temperature acclimation above $0^{\circ} \mathrm{C}$ resulted in a progressive alteration of the lysosomal compartment in digestive gland cells, as shown by cytochemical analyses (lipofuscin and neutral lipid accumulation and lysosomal membrane destabilization). Concurrently, real activities of the antioxidant enzymes superoxide dismutase (SOD) and catalase (i.e. measured at the respective experimental temperature or calculated by means of previously determined $\mathrm{Q}_{10}$ values) increased in gills and digestive gland tissues. Measurements of intracellular $\mathrm{pH}$ at the different temperatures showed a rise from $\mathrm{pH} 7.21$ at $0^{\circ} \mathrm{C}$ to 7.36 at $9^{\circ} \mathrm{C}$. These changes in $\mathrm{pH}$ are indicated to increase SOD activity by approximately $10 \%$ in both kinds of tissue at $9^{\circ}$ as compared to $0^{\circ} \mathrm{C}^{\circ} \mathrm{H}_{2} \mathrm{O}_{2}$ exposure at $4^{\circ} \mathrm{C}$ produced physiological alterations at the systemic (lowered $\mathrm{O}_{2}$ consumption) and at the cellular levels (enhanced lysosome damage). Starvation induced lysosomal alterations in animals kept at $0^{\circ} \mathrm{C}$ and inhibited CAT activation under $\mathrm{H}_{2} \mathrm{O}_{2}$ exposure at $4^{\circ} \mathrm{C}$. The complex of data suggests that when Nacella migrates to intertidal levels during the Austral Spring it experiences oxidative stress which induces an antioxidant response, which is facilitated by higher temperatures and increasing intracellular $\mathrm{pH}$ and the exploitation of intertidal food resources. Yet, the occurrence of cellular damage and systemic alterations shows that the limpets approach their boundaries of physiological tolerance during prolonged exposure to higher temperatures and $\mathrm{H}_{2} \mathrm{O}_{2}$ in intertidal habitats. () 1998 Elsevier Science Inc. All rights reserved.
\end{abstract}

Keywords: Antarctic intertidal; Antioxidant enzymes; $\mathrm{H}_{2} \mathrm{O}_{2}$; Nacella concinna; Oxidative stress; Starvation; Temperature

Abbreviations: CAT, catalase; GPOX, glutathione peroxidase; $\mathrm{MO}_{2}$, oxygen consumption; ROS, reactive oxygen species; SOD, superoxide dismutase; XOD, xanthine oxidase.

* Corresponding author. Tel.: + 49471 4831567; fax: + 49471 4831580; e-mail: abele@awi-bremerhaven.de

\section{Introduction}

Marine ectotherms do not regulate their body temperature independently of temperature variations in the environment. Within certain tolerance boundaries (critical temperatures as defined in [31]), elevated environmental temperatures will therefore stimulate metabolic rate increments. Respiration is a good measure for the 
metabolic rate of a given animal, as it equals the sum of all processes active at the time of the measurement, with the only restriction that it disregards anaerobic energy production. As an estimated proportion, 2-3\% of the oxygen consumed by aerobic cells is converted to oxygen radicals $\left(\mathrm{O}_{2}^{-}\right)$and $\mathrm{H}_{2} \mathrm{O}_{2}[12,33]$ and increasing tissue oxygen consumption will entail elevated rates of ROS (reactive oxygen species) production in mitochondria $[8,9]$. Higher temperatures are therefore prone to enhance ROS release, thereby increasing the risk of oxidative damage.

Radical formation and subsequent damage are balanced by an array of cellular antioxidants. Main antioxidant enzymes such as superoxide dismutase (2 $\left.\mathrm{O}_{2}^{-}+2 \mathrm{H}^{+} \rightarrow \mathrm{H}_{2} \mathrm{O}_{2}+\mathrm{O}_{2}\right)$ and catalase $\left(2 \mathrm{H}_{2} \mathrm{O}_{2} \rightarrow\right.$ $2 \mathrm{H}_{2} \mathrm{O}+\mathrm{O}_{2}$ ) neutralize ROS before they initiate radical chain reactions. Glutathione peroxidase removes $\mathrm{H}_{2} \mathrm{O}_{2}$ and organic hydroperoxides, while other glutathione enzymes catalyze the conjugation of xenobiotics or ROS-damaged cell compounds and provide regeneration of reduced glutathione, thus functioning more as a repair system [36]. Low molecular antioxidants function as radical quenchers and as chain breaking compounds, viz. $\beta$-carotene, the vitamins $\mathrm{A}$ (retinol), $\mathrm{E}$ (tocopherol) and $\mathrm{C}$ (ascorbic acid), glutathione, uric acid and in different organisms also the hemoglobin breakdown products bilirubin and biliverdin [17,35,2].

The nature of stress is, that it impinges a strain on an organism, which cannot be fully balanced by an adaptive response [34]. In case of oxidative stress, this happens when the capacity of the antioxidant system is overwhelmed by the sudden load of ROS released in a tissue and oxidative damage starts to manifest. An example is the ROS release from the microsomal P450 system owing to detoxification of xenobiotic contaminants [29]. Temperature induced ROS release from mitochondria, although a different form of disturbance, apparently produces the same physiological effect, including the increase of antioxidant defense. Thus, intracellular ROS liberation could be a common feature, accompanying physiological strain, owing to a wide range of different ecological disturbances.

Although all classes of macromolecules are susceptible to radical attack, polyunsaturated fatty acids are extremely labile to oxidation owing to their conjugated double bond structures. Higher levels of polyunsaturated fatty acids in biomembranes contribute to preserve membrane fluidity at low temperatures and therewith ensure functioning of integral membrane proteins. At the same time a higher degree of lipid unsaturation could exacerbate membrane susceptibility to radical attack [40], leading to the formation of lipid-hydroperoxides (lipid-OOH).

The present study was designed to evaluate oxidative stress and antioxidant balance in the non-strictlystenothermal Antarctic limpet, Nacella concinna. The animal colonizes shallow water and intertidal habitats in Antarctic and sub-Antarctic coastal areas and the response of oxygen uptake to elevated temperatures has already been intensely studied [28]. These animals, which migrate between shallow subtidal and intertidal habitats $[42,10]$, are exposed to fluctuations of water temperature in intertidal rockpools that on sunny days can reach more than $10^{\circ} \mathrm{C}$ during short periods of $2-4$ $\mathrm{h}$. We also found that during their stay in the intertidal, the animals experience elevated $\mathrm{H}_{2} \mathrm{O}_{2}$ concentrations in-situ. In the Antarctic warm season, $\mathrm{H}_{2} \mathrm{O}_{2}$ can reach micromolar concentrations in surface or intertidal pool water ( $\leq 2 \mu \mathrm{mol} \mathrm{1}^{-1}$, Abele unpublished data), thereby interfering with key physiological processes of animals [1-3].

We experimentally investigated cellular responses originating from limpet exposure to elevated environmental temperatures, also in combination with high external levels of $\mathrm{H}_{2} \mathrm{O}_{2}$ under controlled conditions. Furthermore, considering the general importance of diet for the maintenance of the cell antioxidant machinery [27] and the strong seasonality of food supply in Antarctic sea environments [7], we also tested the effects of starvation on the capabilities of limpets to tolerate oxidative stress.

The effects of oxidative stress were evaluated at the cellular level in terms of lysosome alterations in digestive gland tissues. The lysosomal compartment is in fact an important target of uncontrolled oxidative processes, involving leakage of lysosomal enzymes into the cytosol and thereby leading to severe damage to cells $[24,23]$. Lysosomal membranes are especially susceptible to free radical damage and liberation of lysosomal enzymes can serve as a general marker for radical attack of cellular membranes [26,44]. In addition, accumulation of neutral lipids can also serve as a strictly related index of lysosomal alteration [23], while lipofuscin accumulation is a well known marker of oxidative stress [38]. In this context, analysis of tissue levels of lipid soluable low molecular antioxidants (e.g. tocopherol) would have been an important cue. This was, however, not feasible owing to the restricted availability of experimental animals.

Another question was, how temperature would affect antioxidant enzyme activity. Basically, enzymatic activity is increased at high temperatures according to van Hoff's rule, resulting in a $\mathrm{Q}_{10}$ which generally lies between 2 and 3. A second factor which might modulate antioxidant enzyme activity is a shift of the intracellular acid/base status in response to changing environmental temperatures [31]. Thus, we measured temperature induced changes of the intracellular $\mathrm{pH}$ in limpet tissues and the dependency of SOD activity on $\mathrm{pH}$. In a final approach, we tested the environmental insult that elevated $\mathrm{H}_{2} \mathrm{O}_{2}$ concentrations in seawater represent for limpet metabolism $\left(\mathrm{MO}_{2}\right)$ and the re- 
sponse in term of CAT activity that peroxide exposure elicits in fed and starved animals.

\section{Material and methods}

\subsection{Chemicals}

Naphtol AS-BI $\quad N$-acetyl- $\beta$-D-glucosaminide, Polypep, fast violet B salt, oil red $\mathrm{O}$ and triethylphosphate were from Sigma (St. Louis, MO). The oxyradical probe dihydrorhodamine 123 (DHR) was from Molecular Probes (Eugene, OR). The fluorescent dye $N, N$-diethyl- $p$-phenylenediamine (DPD) and antioxidant enzyme standards were purchased from SigmaAldrich (Germany). All other reagents were of analytical grade.

\subsection{Animal collection and transport}

Specimens of the Antarctic limpet Nacella concinna were collected at Jubany Station, King-George-Island (South Shetland Islands) in February 1996. Animals were sampled by divers from shallow subtidal habitats in 5-7 $\mathrm{m}$ water depth and transported on FS Polarstern to the Alfred-Wegener Institute in Bremerhaven, where they were kept in seawater aquaria at $0^{\circ} \mathrm{C}$. Animals had a mean shell length of $29.8 \pm 3.3 \mathrm{~mm}$ corresponding to a body fresh weight of $2.1 \mathrm{~g}$, calculated according to Favero et al. [15]. We did not distinguish sex or reproductive stage of specimens.

\subsection{Temperature experiments and exposure to $\mathrm{H}_{2} \mathrm{O}_{2}$}

One month before starting the experiments, in October 1996, a batch of 40 animals was isolated and kept without feeding thereafter for starvation experiments. To evaluate the effect of temperature, 30 animals which had been regularly fed were transferred to $4^{\circ} \mathrm{C}$. Two days later, 15 of these animals were transferred to $9^{\circ} \mathrm{C}$. Thereby, the temperature increase from 0 to $9^{\circ} \mathrm{C}$ was achieved in two steps with a 2 day intermediate exposure to $4^{\circ} \mathrm{C}$. Animals were used for analysis after 24 or $48 \mathrm{~h}$ exposure to $4^{\circ} \mathrm{C}$ and after 24 at $9^{\circ} \mathrm{C}$.

In a second experiment, the effect of $\mathrm{H}_{2} \mathrm{O}_{2}$ on fed and starved limpets was tested by exposing animals to concentrations between 3 and $5 \mu \mathrm{mol} 1^{-1}$ over a time of $4 \mathrm{~h}$. The experiment was carried out at $4^{\circ} \mathrm{C}$ and animals were pre-adapted to that temperature for 2 days. Hydrogen peroxide from a $0.2 \mathrm{mmol}^{-1}$ stock solution was added to filtered seawater ( $34 \mathrm{o} / \mathrm{oo}, 2 \mu \mathrm{m})$ at the indicated concentration. The experiment was carried out in the dark to minimize $\mathrm{H}_{2} \mathrm{O}_{2}$-photodestruction. The $\mathrm{H}_{2} \mathrm{O}_{2}$-concentration was controlled fluorimetrically in the incubation water at hourly intervals, using the method by Andreae [5] as described in Abele-
Oeschger et al. [4]. The experimental temperature of $4^{\circ} \mathrm{C}$ was chosen, because, if the animals encounter high hydrogen peroxide levels in their natural habitat, this will be in rockpools on sunny days with intense radiation, which will also lead to warming of the rockpool water (Abele, unpublished data).

\subsection{Assessment of lysosomal alterations}

Lysosomal membrane stability was evaluated by a cytochemical procedure based on $N$-acetyl- $\beta$ hexosaminidase activity (EC 3.2.1.52), an enzyme which participates in lysosomal hydrolase activities. Lysosomal destabilization was measured on cryostat sections (OTF Cryostat, Bright Instrument Company, Huntingdon, UK) and the increased lysosomal permeability to the substrate (naphtol AS-BI $N$-acetyl- $\beta$-D-glucosaminide) visualized by the enzymatic reaction, followed by diazonium coupling. We used a slightly modified version of the protocol as given by Moore $[21,23]$. In particular, sections mounted on slides were treated with $0.1 \mathrm{M} \mathrm{Na}$-citrate- $2.5 \% \mathrm{NaCl}$ (w:v), $\mathrm{pH} 4.5$ at $37^{\circ} \mathrm{C}$ for different times $(0,3,5,10,15,20,30$ and 40 $\mathrm{min}$ ) in order to find out what pre-treatment time was needed to completely destabilize the lysosomal membrane. The labilization period was assessed by measuring lysosomal optical density with a transmission microscope digital imaging system (CUE-2 software, Galai, Israel). Optical density was averaged on four randomly selected fields in each of four sections from different individuals $(n=4)$.

Lipofuscin and unsatured neutral lipid contents of lysosomes were cytochemically determined on cryostat sections as described by Moore [23]. Sections $(n=6)$ were analyzed by digital imaging as described above.

\subsection{Detection of oxyradical production}

Aliquots of crude homogenates from foot tissue were incubated with $30 \mathrm{mM}$ Hepes ( $\mathrm{pH}$ 7.2), $3.2 \mu \mathrm{M}$ dihydrorhodamine 123 (DHR) [14]. DHR is a non-fluorescent derivative which is converted to the fluorescent dye rhodamine 123 upon reaction with ROS. Probe fluorescence signal was detected by using a Perkin Elmer LS $50 \mathrm{~B}$ spectrofluorometer $(\mathrm{ex} .=505 \mathrm{~nm}, \mathrm{em} .=534 \mathrm{~nm}$, slit $=2.5 \mathrm{~nm}$ ). ROS production was expressed as fluorescence increase versus time.

\subsection{Measurements of intracellular $p H\left(p H_{i}\right)$}

Measurements of intracellular $\mathrm{pH}$ were done in gills and occasionally in digestive gland tissue according to Pörtner et al. [30]. Freshly excised tissue was homogenized under liquid nitrogen using a mortar and pestle. Approximately $50 \mathrm{mg}$ frozen tissue powder was mixed with $250 \mu 1$ of ice-cold potassium fluoride medium (160 
mmol $1^{-1}$ ). Nitrilotriacetate was not added because previous tests showed that this chelator affects the measurements, owing to high $\mathrm{Ca}^{2+}$ and $\mathrm{Mg}^{2+}$ levels. After brief mixing on a vortex and 1 min centrifugation at $13000 \times g$, the $\mathrm{pH}$ in the supernatant was measured in a $\mathrm{pH}$ capillary electrode (Radiometer, Copenhagen G297/G2).

\subsection{Antioxidant enzymes}

Catalase (CAT E.C. 1.11.1.6) and superoxide dismutase (SOD E.C. 1.15.1.1) activities in crude homogenates were measured as described elsewhere [11]. SOD was assayed mostly via the quenching of pyrogallol autoxidation according to Marklund and Marklund [20]. Only when $\mathrm{pH}$ dependency of SOD in gill tissue was tested we used the xanthine oxidase/cytochrome c assay according to Livingstone et al. [19]. This was because the xanthine oxidase (XOD) catalyzed generation of $\mathrm{O}_{2}^{-}$was found to be less affected by $\mathrm{pH}$ than the autoxidation of pyrogallol. Glutathione peroxidase (GPOX, E.C. 1.11.1.9) activity was assayed according to Günzler and Flohé [16] with $\mathrm{H}_{2} \mathrm{O}_{2}$ as a substrate as described in Abele-Oeschger et al. [3].

\subsection{Determination of antioxidant enzyme $Q_{10}$}

Antioxidant enzymes were generally assayed at standard assay temperatures of $20^{\circ} \mathrm{C}$. However, $Q_{10}$ values of SOD and CAT were determined on selected samples by simultaneous measurements at 2 different temperatures. This also allowed to infer real enzyme activities of the animals acclimated to different temperatures. A $\mathrm{Q}_{10}$ determination for GPOX activity was not feasible under the applied assay conditions, because activities were already at the limit of determination at $20^{\circ} \mathrm{C}$. For the low temperature assays the sample holder of a Beckmann DU 7400 spectrophotometer was cooled and temperature controlled in the assay cuvettes with a digital thermometer (Physitemp Type T). Whereas the CAT assay posed no problem at temperatures as low as $1.5^{\circ} \mathrm{C}$, this was different for the SOD assay, due to the need of a pre-reaction in which oxygen radicals are generated at a constant rate. Although $\mathrm{O}_{2}^{-}$generation by pyrogallol autoxidation was considerably slowed at lower temperatures, this assay was found to be less affected by temperature than the enzymatic radical production by XOD. However, higher concentrations of pyrogallol had to be used at lower temperatures and controls were run at room temperature to check for the effect of the applied pyrogallol concentrations on SOD activity. In conclusion, it was possible to measure both CAT and SOD activities at 20, 10 and $4^{\circ} \mathrm{C}$, whereas only CAT was measured also at $1.5^{\circ} \mathrm{C}$. SOD activities at $0^{\circ} \mathrm{C}$, when given, have consequently been extrapolated using the Q10 for SOD activity between 20 and $4^{\circ} \mathrm{C}$.

\subsection{Respirometry before and after $\mathrm{H}_{2} \mathrm{O}_{2}$ exposure}

Measurements of oxygen consumption before and after exposure to 3 and $5 \mu \mathrm{mol} \mathrm{H}_{2} \mathrm{O}_{2} 1^{-1}$ in natural seawater were carried out with individual animals. These experiments were performed in the Dallmann laboratory at Jubany Base, King-George Island in January 1997.

Animals used for respirometry were kept at $1{ }^{\circ} \mathrm{C}$ in seawater aquaria for at least 5 days prior to the experiment. Measurements were done at a temperature of $1{ }^{\circ} \mathrm{C}$ in a flow-through respirometer (Fa. Eschweiler Germany) at a constant flow rate of $36 \mathrm{ml} \mathrm{h}^{-1}$, using filtered $(0.2 \mu \mathrm{m}$ poresize $)$ seawater of $34 \mathrm{o} / \mathrm{oo}$ [25]. Animals were cleaned from epiphytic algae by wiping shells with alcohol and placed into the respiration chamber ( $25 \mathrm{ml}$ volume). Experiments started 1-2 h later and lasted for 5-8 h. Oxygen concentrations were recorded at the inlet and the outlet of the chamber with two polarographic oxygen electrodes connected to an oxymeter (M200, Fa. Eschweiler, Germany) and to a Linseis two-channel chart recorder. Before and after each measurement, oxygen consumption of the system without an animal, as well as the electrode drift, were subtracted from the measurements.

Hydrogen peroxide incubations were not done in the respirometer. After respirometric measurements under control conditions, animals were transferred to a glass beaker, containing the indicated $\mathrm{H}_{2} \mathrm{O}_{2}$ concentration in filtered seawater (at 1 to $2^{\circ} \mathrm{C}$ for $5 \mathrm{~h}$ ). During this period, $\mathrm{H}_{2} \mathrm{O}_{2}$ concentration was controlled photometrically by use of a peroxidase-catalyzed reaction with the analytical dye $N, N$-diethyl- $p$-phenylenediamine [6] and readjusted accordingly at hourly intervals. Experiments were carried out in the dark to minimize $\mathrm{H}_{2} \mathrm{O}_{2}$ photodestruction and bacterial growth. Thereafter, the animals were placed back into the respirometer and oxygen consumption recorded again for between 5 and $8 \mathrm{~h}$.

\subsection{Statistics}

Data were analyzed by the InStat software package (Graph Pad, San Diego, CA). Enzyme activity data were analyzed by a simple $t$-test.

\section{Results}

\subsection{ROS production and oxidative by-products}

As an index of oxidative stress, increased ROS production in $N$. concinna tissue was fluorimetrically detected using the DHR probe. The results showed minimal differences among samples deriving from specimens kept at different temperatures above control level 
$\left(0^{\circ} \mathrm{C}\right.$, data not shown $)$. By contrast, increased ROS production was detected in animals exposed to $\mathrm{H}_{2} \mathrm{O}_{2}$ at $4^{\circ} \mathrm{C}(P<0.05)$ with respect to controls at $4^{\circ} \mathrm{C}$, whereas an even higher increase was detected in starved animals exposed to $\mathrm{H}_{2} \mathrm{O}_{2}$ (Fig. 1). Moreover, cytochemical data showed that $\mathrm{H}_{2} \mathrm{O}_{2}$ application at $4^{\circ} \mathrm{C}$ caused a clear-cut increase of lipofuscin content of lysosomes $(P<0.001$, Fig. 2b). Lipofuscin also increased in individuals kept at 4 and $9^{\circ} \mathrm{C}$ with respect to the $0^{\circ} \mathrm{C}$ controls $(P<$ 0.001 , Bonferroni test among 0,4 and $9^{\circ} \mathrm{C}$, Fig. $2 \mathrm{~b}$ ), indicating an accumulation of oxidative by-products under these experimental conditions, despite the fact that no surplus ROS production was detected by DHR analysis.

\subsection{Alteration of lysosome membrane stability and of lysosome contents}

Mollusc digestive glands contain cells which are particularly rich in lysosomal vacuoles [32] and therefore this tissue represents an ideal experimental system for an evaluation of the role of lysosomes in cell physiology and cytotoxicity [22]. The cytochemical analysis of lysosomal membrane stability showed that lysosomal integrity was affected by different factors. Animals acclimated to increasing temperatures showed a significant decrease of lysosome membrane destabilization time, indicating lysosome damage $(P<0.001$, MannWhitney test, Fig. 2a). Lysosome membrane destabilization was also significantly detected after starvation at $0^{\circ} \mathrm{C}(P<0.05$, Mann-Whitney test $)$, which emphasizes the importance of diet in the maintenance of the physiological status of these subcellular structures (Fig. 2a). Moreover, exposure to $\mathrm{H}_{2} \mathrm{O}_{2}$ at $4^{\circ} \mathrm{C}$ severely affected lysosomal membrane stability $(P<0.05$, MannWhitney test) (Fig. 2a).

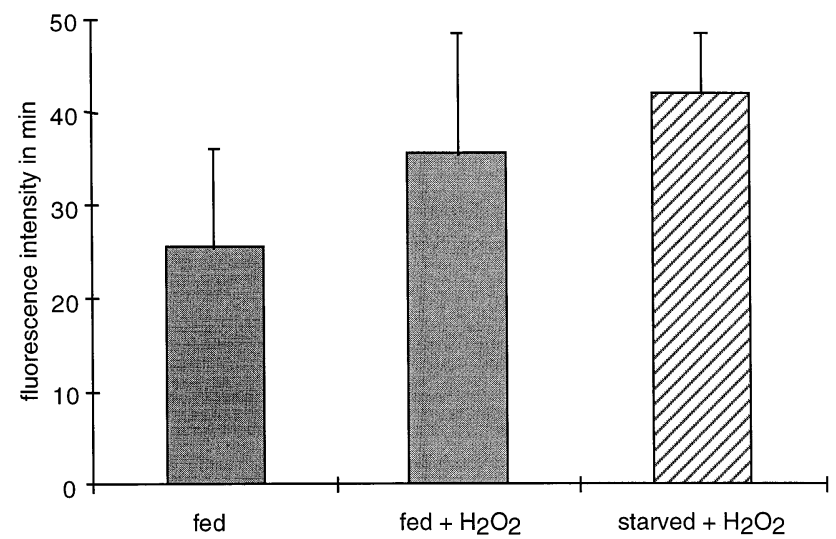

Fig. 1. Effect of $\mathrm{H}_{2} \mathrm{O}_{2}$ exposure on ROS production in crude tissue extracts from fed (filled bars) and starved (hatched bar) individuals of Nacella concinna incubated in vivo at $4^{\circ} \mathrm{C}$. ROS production has been evaluated fluorimetrically by using the oxyradical probe DHR. Data $(n=5)$ are expressed as probe fluorescence intensity $\min ^{-1} \mathrm{mg}^{-1}$ protein (see text for statistical comparisons and significant differences).
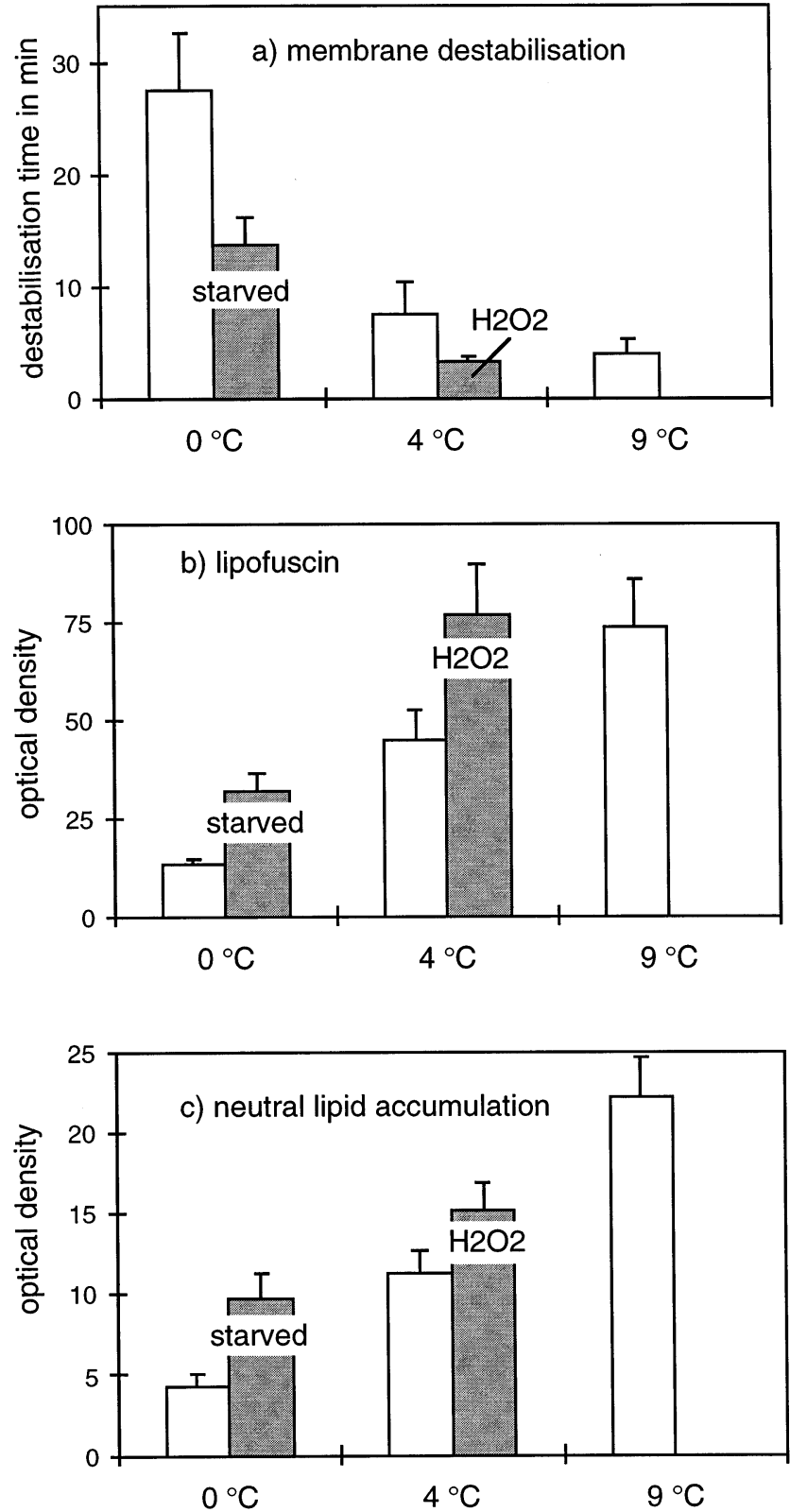

Fig. 2. Effect of different in vivo incubation temperatures on lysosomal membrane stability (a), lipofuscin (b) and neutral lipid accumulation (c) in digestive gland cells, evaluated by cytochemical techniques and image analysis. The effects of starvation at $0^{\circ} \mathrm{C}$ and $\mathrm{H}_{2} \mathrm{O}_{2}$ exposure at $4^{\circ} \mathrm{C}$ are also shown. Data $(n=4-6)$ are expressed as membrane destabilization time for lysosomal membrane stability, and as arbitrary units of optical density for lipofuscin and neutral lipids (see text for statistical comparisons and significant differences).

The data on lysosomal membrane stability related well to the lysosomal content of unsaturated neutral lipids. The latter (Fig. 2c) increased significantly upon acclimation to higher temperatures $(P<0.001$, Bonferroni test among 0,4 and $\left.9^{\circ} \mathrm{C}\right)$, starvation at $0^{\circ} \mathrm{C}$ $(P<0.001)$ and exposure to $\mathrm{H}_{2} \mathrm{O}_{2}$ at $4^{\circ} \mathrm{C}(P<0.001)$. In summary, increasing temperatures, starvation and high $\mathrm{H}_{2} \mathrm{O}_{2}$ levels were all able to induce alterations of the lysosomal vacuolar system. 


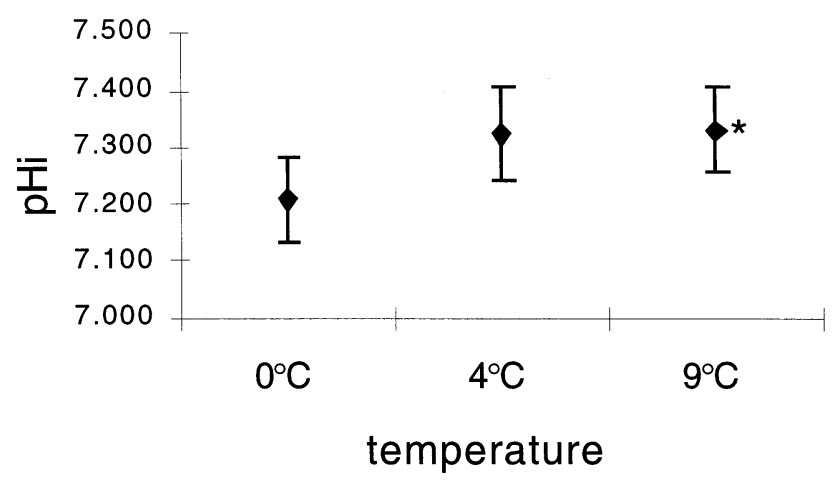

Fig. 3. Intracellular $\mathrm{pH}$ versus incubation temperature in gill tissue $(n=6-12)$. Measurements were made at the respective incubation $\mathrm{T}$. * Significantly different $(P<0.05)$ from the control group $\left(0^{\circ} \mathrm{C}\right)$.

\subsection{Effects of temperature on intracellular $p H$}

Intracellular $\mathrm{pH}$ was measured in gill tissue of limpets which had been kept at $4^{\circ} \mathrm{C}$ for 24 and $48 \mathrm{~h}$ and at $9^{\circ} \mathrm{C}$ for $24 \mathrm{~h}$ and compared to a control group at $0^{\circ} \mathrm{C}$. As no difference was found between the two groups kept for different time intervals at $4^{\circ} \mathrm{C}$, these data were combined to one average value in Fig. 3. The $\mathrm{pH}_{\mathrm{i}}$ in the control group was $7.21 \pm 0.08$. At $4^{\circ} \mathrm{C}$ there was a minor increase, while a significant $\mathrm{pH}$ increment was found between the controls and the group incubated at $9^{\circ} \mathrm{C}(7.36 \pm 0.05, P<0.05)$. Measurements in digestive gland tissue gave identical results as in gills (data not shown).

\subsection{Effect of temperature on antioxidant enzyme activities}

$\mathrm{Q}_{10}$ coefficients of SOD and CAT in gill tissues, are given in Table 1 for various temperature intervals between 1.5 and $20^{\circ} \mathrm{C}$. According to these $\mathrm{Q}_{10}$ values and with the exclusion of CAT activities below $10^{\circ} \mathrm{C}$, a temperature increment of $10^{\circ} \mathrm{C}$ would roughly result in a doubling of both enzyme activities. In other words: a measurement at $20^{\circ} \mathrm{C}$ will over-estimate the real activity of both enzymes under in-situ conditions by $100 \%$. At temperatures below $10^{\circ} \mathrm{C}, \mathrm{CAT} \mathrm{Q}_{10}$ was only 1.3 and

\section{Table 1}

$\mathrm{Q}_{10}$ coefficients for CAT and SOD in gill tissues of Nacella concinna $(n=4-8)$

\begin{tabular}{lcl}
\hline Enzyme & $\mathrm{T}$ increment $\left({ }^{\circ} \mathrm{C}\right)$ & $\mathrm{Q}_{10}$ coefficients $\pm \mathrm{SD}$ \\
\hline SOD & $4-20$ & $2.20 \pm 0.4$ \\
SOD & $10-20$ & $1.70 \pm 0.3$ \\
CAT & $1.5-20$ & $1.60 \pm 0.06$ \\
CAT & $4-20$ & $1.80 \pm 0.1$ \\
CAT & $10-20$ & $1.95 \pm 0.3$ \\
CAT & $1.5-10$ & 1.3 \\
CAT & $1.5-4$ & 1 \\
\hline
\end{tabular}

only 1 between 1.5 and $4^{\circ} \mathrm{C}$. Apparently, there is little effect of temperature on this specific enzyme within the temperature ranges the limpets regularly encounter in intertidal habitats during the Antarctic summer ( $0-$ $9^{\circ} \mathrm{C}$ ). As it was not feasible, to conduct measurements of SOD activity of the same sample at 4 and $10^{\circ} \mathrm{C}$ simultaneously, we cannot exclude that this enzyme will also respond with lower $\mathrm{Q}_{10}$ values to temperature changes below $10^{\circ} \mathrm{C}$. All subsequent measurements were conducted at standard assay conditions of $20^{\circ} \mathrm{C}$ (normalized activities) and real activities were then calculated by applying the previously determined $\mathrm{Q}_{10}$ values (Fig. 4). Starved and fed animals were compared at $0^{\circ} \mathrm{C}$. SOD was measured in both gills and digestive gland, whereas catalase and GPOX were measured in gills only. Thereby we could compare all antioxidant enzymes in the same tissue (the gills), while oxidative damage is better followed in the lipid rich digestive gland. As there was only material left for the analysis of one enzyme, SOD was chosen because it detoxifies oxygen radicals $\left(\mathrm{O}_{2}^{-}\right)$which often are the primary reactive oxygen intermediates during internal ROS generation.

Normalized CAT activities in gill tissue (Fig. 4a) showed a dependency on temperature. At $9^{\circ} \mathrm{C}$, CAT activities were slightly higher than at $4^{\circ} \mathrm{C}$, but they differed significantly from the $0^{\circ} \mathrm{C}$ control group $(P<$ $0.05)$. Animals starved at $0^{\circ} \mathrm{C}$ had significantly lower enzyme activities $(P<0.05)$ than the fed group. Real CAT activities were by far lower, i.e. less than $50 \%$ of normalized activities at $20^{\circ} \mathrm{C}$ in all groups and displayed an increasing trend between 0 and $9^{\circ} \mathrm{C}$. Normalized SOD activities in gill tissue (Fig. 4b) were found to be highest at $4^{\circ} \mathrm{C}$. Real activities showed a drastic increase between 0 and $4^{\circ} \mathrm{C}$ and a further increase at $9^{\circ} \mathrm{C}$. A similar pattern was found in SOD activities of digestive gland tissue (Fig. 4c), although normalized activities were 3-fold higher in digestive gland compared to gills. Apparently, SOD activity in the gills is more susceptible to low temperatures, than in digestive gland. No difference between SOD activities in gills of starved and fed animals at $0^{\circ} \mathrm{C}$ was observed, whereas SOD activity was reduced by $30 \%$ in the digestive gland of starved specimens.

Normalized GPOX activities versus temperature are given in Fig. 4d. This enzyme displayed highest activities at $0^{\circ} \mathrm{C}$ with no apparent difference between starved and fed specimens. Activities were reduced by nearly $50 \%$ at $4^{\circ} \mathrm{C}$, while at $9^{\circ} \mathrm{C}$ the activity was nearly back to the $0^{\circ} \mathrm{C}$ control level.

\subsection{Effect of $\mathrm{H}_{2} \mathrm{O}_{2}$ on metabolic rates and on $\mathrm{CAT}$ activity}

Table 2 gives rates of oxygen consumption $\left(\mathrm{MO}_{2}\right)$ of individual limpets (at $1-2^{\circ} \mathrm{C}$ ) before and after exposure 

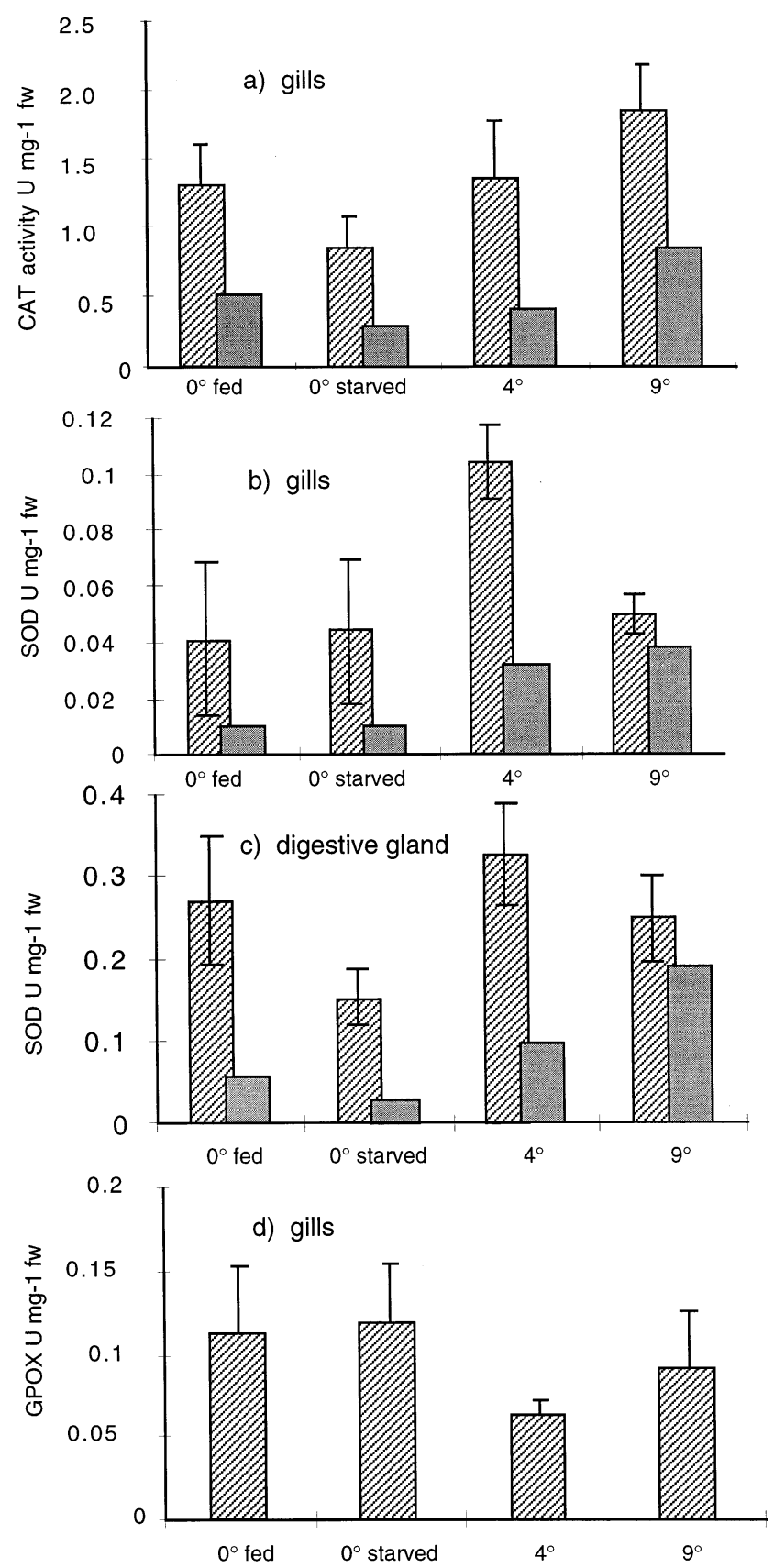

Fig. 4. Effect of temperature on normalized (hatched bars) and real, $\mathrm{Q}_{10}$ corrected (filled bars) antioxidant enzyme activities. (a) CAT in gills, (b) SOD in gills, (c) SOD in digestive gland, (d) GPOX in gills. Data are expressed as $\mathrm{U}$ enzyme activity $\mathrm{mg}^{-1}$ tissue fresh weight $(n=4-8)$. At $0^{\circ} \mathrm{C}$ data were obtained from fed and starved individuals.

to hydrogen peroxide at 3 and $5 \mu \mathrm{mol} 1^{-1} \cdot \mathrm{H}_{2} \mathrm{O}_{2}$ had an effect on limpet aerobic metabolic rates only at a concentration of $5 \mu \mathrm{mol} 1^{-1}$ (45\% reduction of mean $\mathrm{MO}_{2}$ ), whereas exposure to $3 \mu \mathrm{mol} 1^{-1} \mathrm{H}_{2} \mathrm{O}_{2}$ had no effect on oxygen uptake rates.

Under experimental exposure at $4^{\circ} \mathrm{C}$, the capacity to break down $\mathrm{H}_{2} \mathrm{O}_{2}$ was clearly higher in well fed animals, which decomposed about half of the added $\mathrm{H}_{2} \mathrm{O}_{2}$ during the $4 \mathrm{~h}$ incubation period (Fig. 5a). Conversely, after $2 \mathrm{~h}$ of $\mathrm{H}_{2} \mathrm{O}_{2}$ exposure the capacity of the starved animals to decompose $\mathrm{H}_{2} \mathrm{O}_{2}$ was expired. Consistent with the ability to break down $\mathrm{H}_{2} \mathrm{O}_{2}$, animals which had been fed prior to $\mathrm{H}_{2} \mathrm{O}_{2}$ exposure were able to increase CAT activity from a control value of $1.356 \pm$ 414 to $1.781 \pm 541\left(\mathrm{U} \mathrm{mg}^{-1} \mathrm{fw}\right)$ by the end of the exposure, whereas in starved animals exposed to $\mathrm{H}_{2} \mathrm{O}_{2}$ CAT activity resulted lower than in controls $(1.118 \pm$ $250 \mathrm{U} \mathrm{mg}^{-1} \mathrm{fw}$, see Fig. 5b). Thus, post-incubatory CAT activities displayed a significant difference between the starved and the fed group $(P<0.05)$ of $\mathrm{H}_{2} \mathrm{O}_{2}$-exposed animals, whereas neither group was significantly different from the non-exposed control group.

\subsection{Effect of pH on SOD activity}

SOD activity in samples from gill and digestive gland tissue was compared for individual samples at $\mathrm{pH} 7.8$ (original assay $\mathrm{pH}$ ) and at $\mathrm{pH} 7.2$ and 7.4, because, according to our $\mathrm{pH}_{\mathrm{i}}$ measurements (see above), this is the relevant $\mathrm{pH}$ range for Nacella tissue between 0 and $9^{\circ} \mathrm{C}$. Data at $\mathrm{pH} 7.8$ were taken as $100 \%$ activity, while percent reduction was calculated for each step towards lower $\mathrm{pH}$. SOD activity in gills was not reduced at $\mathrm{pH}$ $7.4(n=3)$, whereas at $\mathrm{pH} 7.2$ a $10 \%$ reduction of SOD activity was found $(n=2)$. In digestive gland, $\mathrm{pH} 7.4$ resulted in a $9 \%(n=3)$ and $\mathrm{pH} 7.2$ in a $20 \%$ reduction of SOD activity $(n=2)$. Thus, SOD activity in the latter tissue appears slightly more susceptible to $\mathrm{pH}$ changes.

\section{Discussion}

Antarctic marine ectotherms colonizing intertidal habitats experience transient periods of higher temperatures due to sunlight warming of intertidal pools during low tides, a process which is moreover accompanied by UV-driven $\mathrm{H}_{2} \mathrm{O}_{2}$ accumulation $[4,40]$. Therefore, these animals are likely to undergo rapid intensification of pro-oxidant processes and their survival in intertidal habitats should partly depend on their capacity to rapidly activate the antioxidant defense system. Because of its seasonal migrations to intertidal areas during the Antarctic Spring [42], the limpet $N$. concinna is particularly interesting in this respect.

In this study, a set of experiments was designed to investigate the possible occurrence of oxidative stress in limpets acclimated to temperatures above basic Antarctic seawater levels $\left(-1\right.$ to $\left.2^{\circ} \mathrm{C}\right)$. The cytochemical assessment of lysosomal alterations showed that increasing environmental temperatures can have a significant impact on cell physiology. Already at an ambient temperature of $4^{\circ} \mathrm{C}$, lysosome membranes became destabilized and the accumulation of lipofuscin was 
increased, while at $9^{\circ} \mathrm{C}$ these processes were significantly intensified. The alteration of the lysosomal vacuolar system was further testified by neutral lipid accumulation, a parameter which is known to be correlated with membrane destabilization [23], and could be indicative of altered lipid metabolism, possibly combined with increased autophagy.

Both, lipofuscin accumulation and membrane destabilization argue strongly for an effect of oxidative stress, involving lipid peroxidation and formation of oxidative by-products as a consequence of the increased catabolic activity $[44,39]$. Our data indicate that during the $24 / 48 \mathrm{~h}$ exposure to temperatures above $0^{\circ} \mathrm{C}$, prooxidant processes caused a progressive cellular damage. However, measurements performed with the fluorescent probe DHR showed that at the end of incubations above $0^{\circ} \mathrm{C}$ increased ROS production was not detectable, with the clear exception of $\mathrm{H}_{2} \mathrm{O}_{2}$ treatments at $4^{\circ} \mathrm{C}$. Obviously, exposure to higher temperatures alone induces compensatory effects, i.e. the activation of antioxidant systems.

An additional evidence for an antioxidant response at elevated temperatures, was provided by the antioxidant enzyme assays. Estimates of $\mathrm{Q}_{10}$, obtained for SOD and CAT, allowed to deduce real activities. Yet, the patterns of normalized enzyme activities clearly showed differences concerning the inducibility of different antioxidant enzymes.

The physiological implication of normalized activities, measured at a standard temperature of $20^{\circ} \mathrm{C}$, is that they allow to compare the catalytic activity in selected tissues and to reveal changing amounts of active enzyme with increasing ambient temperatures. A high standard activity, therefore, reflects a higher amount of catalytically active enzyme per unit tissue. Hence, the standard (i.e. normalized) antioxidant enzyme activities may also be an appropriate measure to compare various tissues for their response to physiological strain, as long as it involves ROS production. By contrast, real activities reflect the true rates of antioxidant enzymes under specific environmental conditions.

The most prominent response of normalized enzyme activity was found for gill SOD between 0 and $4^{\circ} \mathrm{C}$. This coincides with a previously found transient overshoot of Nacella's oxygen uptake upon temperature increase from 1.5 to $3^{\circ} \mathrm{C}$, which resulted in an extreme $\mathrm{Q}_{10}$ of 20 [28]. However, by comparing normalized and real SOD activities at $4^{\circ} \mathrm{C}$, it seems that the effective protection against radical damage amounts to only one third of the antioxidant potential, measurable at $20^{\circ} \mathrm{C}$ and it stays speculative whether the effort the animals invest into new enzyme synthesis will pay off to satisfy their needs for protection. Between 4 and $9^{\circ} \mathrm{C}$ no further induction of SOD activity was observed, which is congruent with a lesser effect of temperature on oxygen uptake above $4^{\circ} \mathrm{C}\left(\mathrm{Q}_{10}\right.$ between 0.8 and 2) [28]. The combination of lysosome membrane destabilization, lipofuscin and neutral lipid accumulation, together with the reduction of SOD activity in both tissues at $9^{\circ} \mathrm{C}$ demonstrates how elevated temperatures can induce tissue damage in cold adapted invertebrates.

Effects of starvation at $0^{\circ} \mathrm{C}$ were minor and appeared only in gill CAT and digestive gland SOD data, whereas SOD and GPOX in gills were not reduced. However, the reduction was decisive enough to elicit an increased manifestation of oxidative damage in diges-

Table 2

Oxygen consumption $\left(\mathrm{MO}_{2}\right)$ in $N$. concinna before and after exposure to hydrogen peroxide at concentrations of 3 and $5 \mu$ mol $1^{-1}$

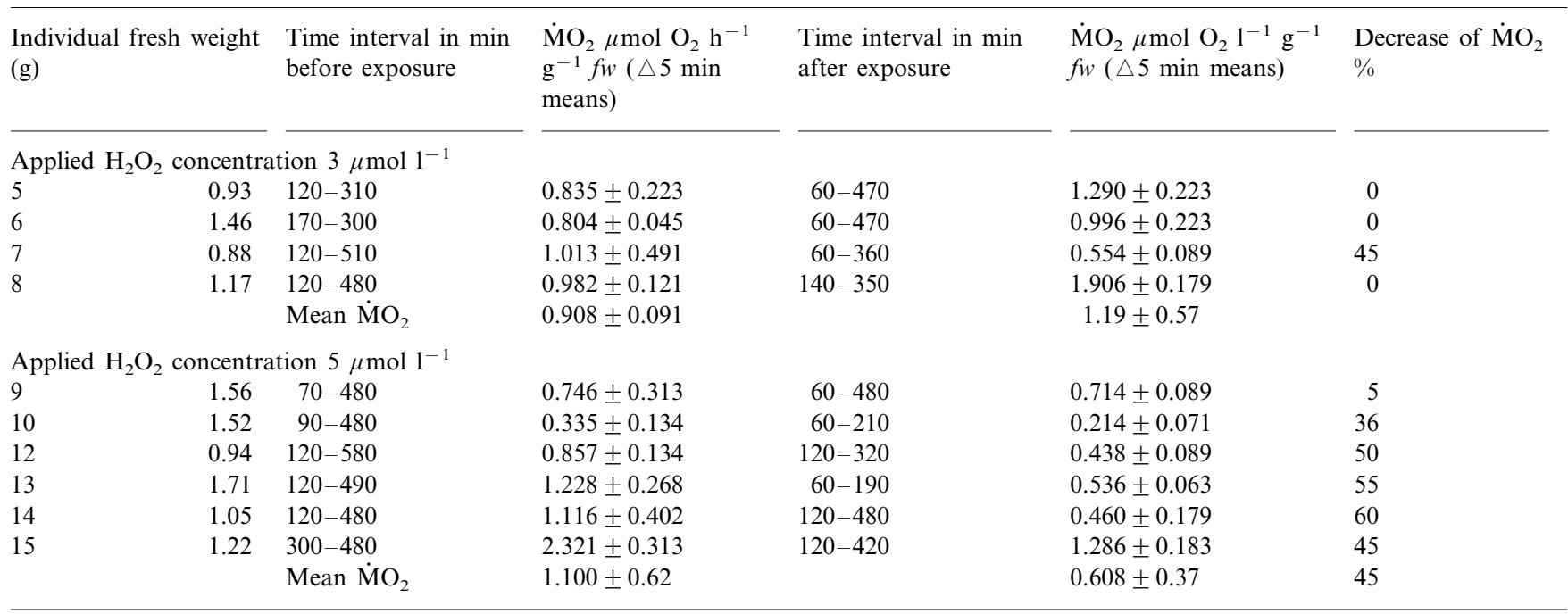

Experiments were performed in filtered seawater at $1{ }^{\circ} \mathrm{C}$. The time interval utilized in the calculation started after an acclimation period of the animals to the incubation system, which was usually between 1 and $2 \mathrm{~h}$ after insertion of the animals into the respirometer. Registration of no. 15 started later, due to technical problems. Oxygen consumption was calculated for 5 min intervals. 


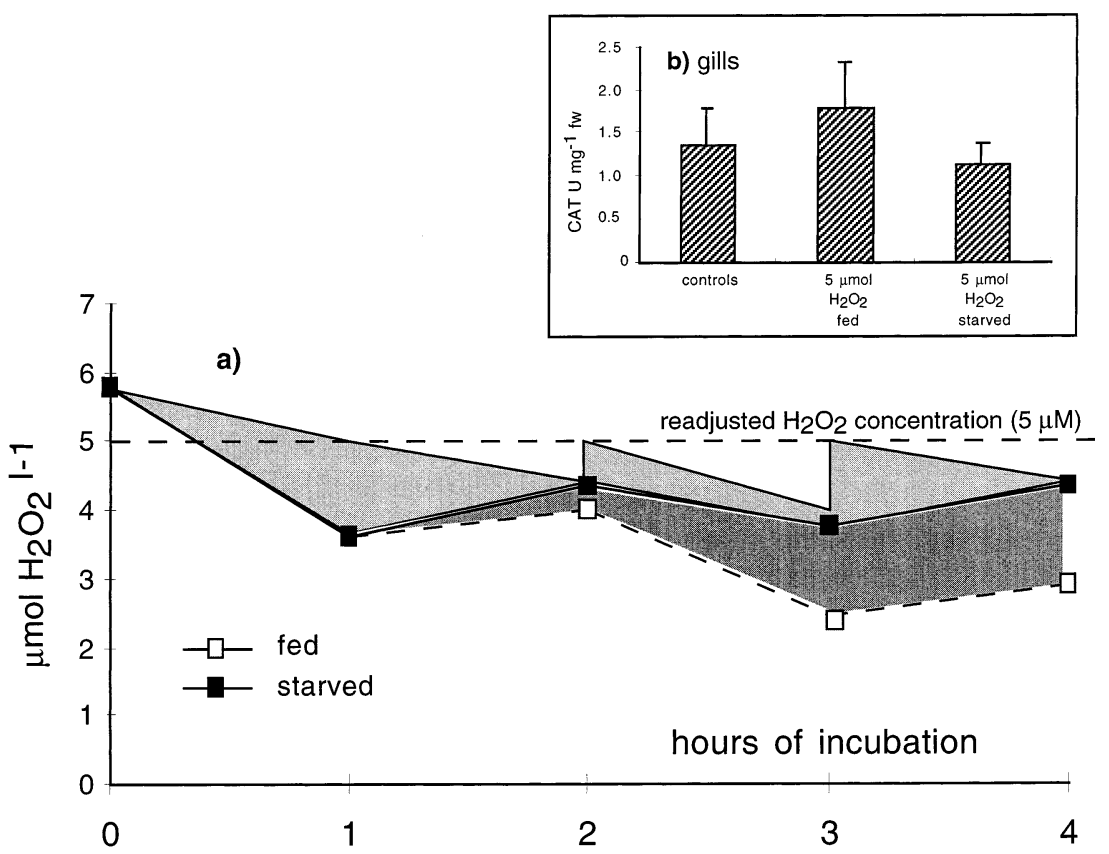

Fig. 5. $\mathrm{H}_{2} \mathrm{O}_{2}$-breakdown during $4 \mathrm{~h}$ of exposure at a concentration of between 3 and $5 \mu$ mol $1^{-1}$ by starved and fed individuals (a) and the resulting CAT activity in gill tissue after the incubation (b) $(n=6-8)$. After $1 \mathrm{~h}$ the $\mathrm{H}_{2} \mathrm{O}_{2}$ concentration had decreased by the same amount in both experimental jars. Thereafter, fed individuals ( $\square$ ) displayed a far better ability to decompose $\mathrm{H}_{2} \mathrm{O}_{2}$ as compared to starved specimens ( $\square$ ).

tive gland tissue of starved animals, as shown by cytochemical data and presumably this will also apply to the gills. It should be noted that the cellular levels of different low molecular-weight antioxidants, such as vitamin $\mathrm{C}, \mathrm{E}$ and carotenoids, but also $\mathrm{GSH}$, are in general related to the diet [27]. A deficit of these compounds could thus become a critical factor with regard to the antioxidant potentials of a starved animal and further investigation could clarify the relative importance of the different antioxidant systems under different environmental conditions.

What may further exacerbate cellular damage is the onset of phospholipase $\mathrm{A}_{2}$ liberation, from destabilized lysosomes [18]. In many organisms, such an effect could be counterbalanced by a frequently found tissue acidification at higher temperatures, known as the $\alpha$-stat hypothesis [31], because phospholipase $\mathrm{A}_{2}$ activity is substantially reduced when $\mathrm{pH}_{\mathrm{i}}$ drops to 7.0. Yet, this does not seem to apply to the investigated Antarctic species. After the bivalve Limopsis marionensis [31], $N$. concinna is the second Antarctic mollusc in which we find a comparably low $\mathrm{pH}_{\mathrm{i}}$ at $0^{\circ} \mathrm{C}$ and moreover, a shift to higher instead of lower $\mathrm{pH}_{\mathrm{i}}$ with rising temperature. Although this shift by $0.1 \mathrm{pH}$ units seems of minor significance, the lack of acidification may result critical in terms of cellular damage.

When Nacella migrates into the intertidal during Spring and Summer, it is exposed to elevated $\mathrm{H}_{2} \mathrm{O}_{2}$ concentrations from atmospheric input and also from UV-driven activation of dissolved organic matter $[4,40]$. In our experiments, such a situation was simulated by exposing animals kept at $4^{\circ} \mathrm{C}$ to roughly the double maximum natural $\mathrm{H}_{2} \mathrm{O}_{2}$ concentration. To our knowledge, this is the first time that the effect of environmental peroxide on marine invertebrates is tested in a comprehensive approach. This includes systemic effects, i.e. the reduction of aerobic metabolic rates, which are in line with previous findings [2,3], as well as cellular effects including ROS production and the resulting radical damage. Cytochemical data on lysosomal alterations clearly demonstrated that the combined effects of temperature and $\mathrm{H}_{2} \mathrm{O}_{2}$ are additive, which means that environmental $\mathrm{H}_{2} \mathrm{O}_{2}$ accumulation can exacerbate oxidative stress in animals already disturbed by elevated water temperatures in tide pools. Photochemically induced accumulation of $\mathrm{H}_{2} \mathrm{O}_{2}$ of $5 \mu \mathrm{mol}^{-1}$ and more has been measured in temperate intertidal areas during low tides. This is due to exposure of small water bodies, containing high amounts of photoactive dis-

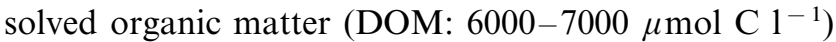
to solar radiation in shallow tidal pools [4]. In the near shore environment of Potter Cove, highest $\mathrm{H}_{2} \mathrm{O}_{2}$ water concentrations were around $2 \mu \mathrm{mol} 1^{-1}$ in spite of far lower DOM-concentrations (between 100 and $300 \mu \mathrm{mol}$ $\mathrm{C}^{-1}$, Abele unpublished results). During our measurements (October-December 1995), $\mathrm{H}_{2} \mathrm{O}_{2}$ accumulation resulted from atmospheric wet deposition of snow. This may, however, be different in the vicinity of penguin rookeries, as well as of Antarctic bases with uncontrolled waste water discharge. Thus, to date, $\mathrm{H}_{2} \mathrm{O}_{2}$ accumulation in Antarctic intertidal environments remains a largely unpredictable factor, also with respect 
to invertebrate ecophysiology in changing polar environments.

Despite increased cellular damage, $N$. concinna responded to $\mathrm{H}_{2} \mathrm{O}_{2}$ exposure by further activating catalase, as shown by increased enzyme activity and $\mathrm{H}_{2} \mathrm{O}_{2}$ decomposition in the incubation seawater (Fig. 5). In this context, the role of nutrition became particularly apparent, indicating that the response to noxious $\mathrm{H}_{2} \mathrm{O}_{2}$ concentrations while enduring temperatures above $0^{\circ} \mathrm{C}$, is probably beyond the possibilities of starved individuals.

$\mathrm{H}_{2} \mathrm{O}_{2}$ is an uncharged molecule and thus easily diffusible across cellular membranes including the gill epithelium. As stated by Wilhelm-Filho et al., [43] fish are able to equilibrate between $\mathrm{H}_{2} \mathrm{O}_{2}$-blood and surrounding water concentrations by excreting $\mathrm{H}_{2} \mathrm{O}_{2}$ through the gills. By contrast, if $\mathrm{H}_{2} \mathrm{O}_{2}$ water concentrations exceed the concentrations in body fluids and tissues, $\mathrm{H}_{2} \mathrm{O}_{2}$ is obviously taken up via the gills and metabolized or accumulated in body fluids and surrounding tissues. Exposing marine invertebrates to elevated $\mathrm{H}_{2} \mathrm{O}_{2}$-concentrations, we have generally observed that the animals break down the $\mathrm{H}_{2} \mathrm{O}_{2}$ in the incubation water $[1-3,11]$. Obviously, the animals strive to control the levels of this highly toxic agent not only within their tissues, but also in their environment as long as this is possible.

In summary, the complex of our data suggests that when cold-adapted limpets migrate into intertidal areas, they are indeed exposed to increased oxidative strain, at least during transient periods of daytime ebb tides with enhanced irradiation (water warming) and substantial atmospheric wet deposition which can also contain high loads of $\mathrm{H}_{2} \mathrm{O}_{2}$ [40]. The investigated limpets seem able to respond to these conditions by intensifying their antioxidant defense, which corroborates previous data on Antarctic ectotherms as being well equipped with cellular antioxidants to tackle oxidative stress [40,41]. In addition, our experiments emphasize the role of food for the animals' capacities to survive internal and external ROS attack. However, our data also indicate that a prolonged exposure to temperatures of various degrees above $0^{\circ} \mathrm{C}$ may overwhelm an organism's defense, by reducing the activity of thermo-labile antioxidant enzymes (e.g. SOD) and by increasing internal ROS production which will entail oxidative damage of subcellular structures, thereby possibly affecting whole animal physiology on a systemic level.

This experimental study is also of some ecophysiological significance. Primarily, the massive presence of a species like $N$. concinna emphasizes the advantage that intertidal environments offer in terms of food web dynamics in Antarctic litoral ecosystems. Nevertheless, our data indicate that variations of temperature (between 0 and $4^{\circ} \mathrm{C}$ ) together with elevated environmental $\mathrm{H}_{2} \mathrm{O}_{2}$-levels could cause some perturbation of limpet physiology. Given that oxidative stress affects Antarctic marine ectotherms in intertidal habitats, it is likely that such strain may superimpose and even worsen the cytotoxic effects of other injurious agents. It is, therefore, conceivable that various aspects of global change, able to promote pro-oxidant processes, such as ozone layer reduction [4] or planet-scale xenobiotic contamination [13,37], could seriously imperil life in Antarctic shallow water and intertidal habitats.

\section{Acknowledgements}

Petra Wencke carried out the respirometry experiments during the Jubany campaign 1997. Thanks go to Dr Rita Fabbri for technical support with cytochemical procedures. D.A. would like to thank the Alfred-Wegener Institute (Bremerhaven) as well as the Instituto Antartico Argentino (Buenos Aires) for supporting research at the Dallmann Laboratory in Jubany. This work was funded by the Italian National Program for Antarctic Research (A.V. and B.B.) and by a research grant of the German Science Foundation (DFG $\mathrm{Ab}$ 64/1-3) to D.A. and H.O.P. This is Alfred-Wegener-Institute publication no. 1362 .

\section{References}

[1] Abele-Oeschger D, Buchner T. Effect of environmental hydrogen peroxide accumulation on filtration rates of the intertidal bivalve clam Cerastoderma edule. Verh Dtsch Zool Ges 1995;88:93.

[2] Abele-Oeschger D, Oeschger R, Theede H. Biochemical adaptations of Nereis diversicolor (Polychaeta) to temporarily increased hydrogen peroxide levels in intertidal sandflats. Mar Ecol Prog Ser 1994;106:101-10.

[3] Abele-Oeschger D, Sartoris FJ, Pörtner HO. Hydrogen peroxide causes a decrease in aerobic metabolic rate and in intracellular $\mathrm{pH}$ in the shrimp Crangon crangon. Comp Biochem Physiol 1997;117C:123-9.

[4] Abele-Oeschger D, Tüg H, Röttgers R. Dynamics of UV-driven hydrogen peroxide formation on an intertidal sandflat. Limnol Oceanogr 1997;42(6):1406-15.

[5] Andreae WA. A sensitive method for the estimation of hydrogen peroxide in biological materials. Nature 1955;175:859-60.

[6] Bader H, Sturzenegger V, Hoigné J. Photometric method for the determination of low concentrations of hydrogen peroxide by the peroxidase catalyzed oxidation of $N, N$-diethyl- $p$-phenylendiamine (DPD). Water Res 1988;22:1109-15.

[7] Barnes DKA, Clarke A. Seasonality of feeding activity in Antarctic suspension feeders. Polar Biol 1995;15:335-40.

[8] Boveris A, Chance B. The mitochondrial generation of hydrogen peroxide. Biochem J 1973;134:707-16.

[9] Boveris A, Cadenas E, Stoppani AOM. Role of ubiquinone in the mitochondrial generation of hydrogen peroxide. Biochem $\mathbf{J}$ 1976;156:435-44.

[10] Brêthes JC, Ferreyra G, de la Vega S. Distribution, growth and reproduction of the limpet Nacella (Patinigera) concinna (Strebel 1908) in relation to potential food availability, in Esperanza Bay (Antarctic Peninsula). Polar Biol 1994;14:161-70. 
[11] Buchner T, Abele-Oeschger D, Theede H. Aspects of antioxidant status in the polychaete Arenicola marina: tissue and subcellular distribution and reaction to environmental hydrogen peroxide and elevated temperatures. Mar Ecol Progr Ser 1996;143:14150 .

[12] Chance B, Sies H, Boveris A. Hydroperoxide metabolism in mammalian organs. Physiol Rev 1979;59(3):527-605.

[13] Courtney WAM, Langston WJ. Organochlorines in Antarctic marine systems. Br Antarct Surv Bull 1981;53:255-7.

[14] Emmendörffer A, Hecht M, Lohmann-Matthes ML, Roesler JA. Fast and easy method to determine the production of reactive oxygen intermediates by human and murine phagocytes using dihydrorhodamine 123. J Immunol Meth 1990;131:269-75.

[15] Favero M, Silva P, Ferreyra G. Trophic relationships between the Kelp Gull and the Antarctic Limpet at King George Island (South Shetland Islands, Antarctica) during the breeding season. Pol Biol 1997;17:431-6.

[16] Günzler WA, Flohé L. Glutathione peroxidase. In: Greenwald RA, editor. CRC Handbooks of Methods for Oxygen Radical Research. Boca Raton, FL: CRC Press, 1985:285-9.

[17] Halliwell B, Gutteridge JMC, Free Radicals in Biology and Medicine, Clarendon Press, London, 1985, pp. 86-179.

[18] Lemasters JJ, Bond JM, Currin RT, et al. Reperfusion injury to heart and liver cells: protection by acidosis during ischemia and a, $\mathrm{pH}$ paradox after reperfusion. In: Hochachka PW, Lutz PL, Sick T, Rosenthal M, van den Thillart G, editors. Surviving Hypoxia: Mechanisms of Control and Adaption. Boca Raton: CRC Press, 1993:495-507.

[19] Livingstone DR, Lips F, Garcia Martinez P, Pipe RK. Antioxidant enzymes in the digestive gland of the common mussel Mytilus edulis. Mar Biol 1992;112:265-76.

[20] Marklund S, Marklund G. Involvement of the superoxide anion radical in the autooxidation of pyrogallol and a convenient assay for superoxide dismutase. Eur J Biochem 1974;47:469-79.

[21] Moore MN. Cytochemical demonstration of latency of lysosomal hydrolases in digestive cells of the common mussel, Mytilus edulis and changes induced by thermal stress. Cell Tissue Res 1976;175:279-87.

[22] Moore MN. Cellular responses to pollutants. Mar Pollut Bull 1985;16:134-9.

[23] Moore MN. Cytochemical responses of the lysosomal system and NADPH-ferrihemoprotein reductase in molluscan digestive cells to environmental and experimental exposure to xenobiotics. Mar Ecol Prog Ser 1988;46:81-9.

[24] Nott JA, Moore MN. Effects of polycyclic haromatic hydrocarbon on molluscan lysosomes and endoplasmic reticulum. Histochem J 1987;19:357-68.

[25] Oeschger R, Peper H, Graf G, Theede H. Metabolic responses of Halicryptus spinulosus (Priapulida) to reduced oxygen levels and anoxia. J Exp Mar Biol Ecol 1992;162:229-41.

[26] Olsson GM, Svensson I, Zdolsek JM, Brunk UT. Lysosomal enzyme leakage during the hypoxanthine xanthine oxidase reaction. Virchows Arch 1989;56B:385-91.

[27] Ong ASH, Packer L, Lipid-Soluble Antioxidants: Biochemistry and Clinical Applications, Mol Cell Biol Updates, Birkhäuser, Basle, 1992, pp. 1-640.
[28] Peck LS. Temperature and basal metabolism in two Antarctic marine herbivores. J Exp Mar Biol Ecol 1989;127:1-12.

[29] Pellerin-Massicotte J. Oxidative processes as indicators of chemical stress in marine bivalves. J Aquat Ecosyst Health 1994;3(2):101-11.

[30] Pörtner HO, Boutilier RG, Tang Y, Toews DP. Determination of intracellular $\mathrm{pH}$ and $\mathrm{PCO}_{2}$ after metabolic inhibition by fluoride and nitrilotriacetic acid. Res Physiol 1990;81:255-74.

[31] Pörtner HO, Hardewig I, Sartoris FJ, van Dijk PLM. Energetic aspects of cold adaptation: adaptation: critical temperatures in metabolic, ionic and acid-base regulation? In: Pörtner HO, Playle R, editors. Cold Ocean Physiology, Cambridge: Cambridge University Press, 1988;88-120.

[32] Robledo Y, Cajaraville MP. Ultrastructural and cytochemical study of the Golgi complex of molluscan (Mytilus galloprovincialis) digestive cells. Cell Tissue Res 1996;284:449-58.

[33] Sohal RS, Weindruch R. Oxidative stress, caloric restriction and aging. Science 1996;273:59-63.

[34] Stebbing ARD. Stress, health and homeostasis. Mar Pollut Bull 1981;12(10):326-9.

[35] Stocker R, Yamamoto Y, McDonagh AF, Glazer AN, Mames BN. Bilirubin is an antioxidant of possible physiological importance. Science 1987;235:298-9.

[36] Storey KB. Oxidative stress: animal adaptations in nature. Braz J Med Biol Res 1996;29:1715-33.

[37] Tanabe S, Hidaka H, Tatsukawa R. PCBs and chlorinated hydrocarbon pesticides in Antarctic atmosphere and hydrosphere. Chemosphere 1983;12:277-88.

[38] Tappel L. Lipid peroxidation and fluorescent molecular damage to membranes. In: Trump BF, Arstila AV, editors. Pathobiology of Cell Membranes. New York: Academic Press, 1975:145-69.

[39] Thaw H, Collins PV, Brunk UT. Influence of oxygen tension, pro-oxidants and antioxidants on the formation of lipid peroxidation products (lipofuscin) in individual cultivated human glial cells. Mech Ageing Dev 1984;24:211-23.

[40] Viarengo A, Abele-Oeschger D, Burlando B, Effects of low temperature on pro-oxidant processes and antioxidant denfense systems in marine organisms In: Pörtner HO, Playle R, editors. Cold Ocean Physiology, Cambridge University Press: Cambridge, 1998;212-83.

[41] Viarengo A, Canesi L, Garcia Martinez P, Peters LD, Livingstone DR. Pro-oxidant processes and antioxidant defense systems in the tissues of the Antarctic scallop (Adamussium colbecki) compared with the Mediterranean scallop (Pecten jacobaeus). Comp Biochem Physiol 1995;111B:119-26.

[42] Walker AJM. Introduction to the ecology of the Antarctic limpet Patinigera polaris at Signy Island, South Orkney Islands. Br Antarct Surv Bull 1972;28:49-69.

[43] Wilhelm-Filho D, González-Flecha B, Boveris A. Gill diffusion as a physiological mechanism for hydrogen peroxide elimination by fish. Braz J Med Biol Res 1994;27:2879-82.

[44] Winston GW, Moore MN, Straatsburg I, Kirchin MA. Decreased stability of digestive gland lysosomes from the common mussel Mytilus edulis L. by in vitro generation of oxygen-free radicals. Arch Environ Contam Toxicol 1991;21:401-8. 